\title{
Pasje intelektualne i ich selektywna funkcja w koncepcji poznania naukowego w Personal knowledge Michaela Polanyiego
}

Twórczość Michaela Polanyiego stanowi bardzo ciekawy wątek $\mathrm{w}$ historii filozofii nauki. Jednak w wielu opracowaniach polskich jego nazwisko pojawia się rzadko i jedynie wzmiankowo. Wzmianki te najczęściej mówią o postulowanych przez węgierskiego myśliciela pozaracjonalnych składnikach nauki, o istnieniu istotnej wiedzy, której nie jesteśmy w stanie wyartykułować, oraz o wpływie Polanyiego na filozofię takich myślicieli, jak Thomas Kuhn czy P. Paul Feyerabend. Te fragmentaryczne informacje sa na tyle interesujące, że zachęcają do pogłębionych badań w celu zrozumienia koncepcji autora Personal knowledge oraz ujęcia jej w kontekście historii refleksji nad nauka. Tym bardziej zreszta, że przy powzięciu takich prób bardzo szybko okazuje się, że na polskim gruncie naukowym opracowań myśli Polanyiego jest zastanawiająco mało. Właściwie naszych rodzimych autorów, którzy stworzyli obszerniejsze opracowania myśli węgierskiego myśliciela, można wymienić zaledwie dwóch - są nimi Barbara Tuchańska ${ }^{1}$ i Iwo Zmyślony². Można także

1 Por. B. Tuchańska, Koncepcja poznania i nauki Michaela Polanyiego, „Acta Universitatis Wratislaviensis”, Socjologia XV: Nauka, demokracja, autorytaryzm. Społeczne i kulturowe wymiary nauki, red. W. Sitek, Wrocław 1994, s. 105-127 oraz Personal knowledge. Towards a post-critical philosophy, [w:] Przewodnik po literaturze filozoficznej XX wieku, red. B. Skarga, Warszawa 1994, s. 400-405.

2 Por. I. Zmyślony, Filozof nauki czy teoretyk poznania? Przyczynek do badań nad pogladami filozoficznymi Michaela Polanyiego, „Filozofia Nauki”, R. XVI, 2008, 
wymienić tylko kilku myślicieli, którzy dokonali bardziej lub mniej szczegółowej analizy poglądów Polanyiego, w mniejszym (m.in. Wojciech $\mathrm{Sady}^{3}$ ) lub większym stopniu (m.in. Józef Życiński ${ }^{4}$, Elżbieta Pietruska-Madej ${ }^{5}$ ) przyznając im wagę dla filozofii i metodologii nauki. Chociaż inaczej rzecz ma się za granica, gdzie Polanyi jest autorem rozpoznawanym i uznawanym za autora oryginalnej filozofii poznania, a jego nazwisko wymienia się wśród czołówki światowych metodologów, to pomimo wszystko można i tam zaobserwować pojawiajace się tendencje do marginalizowania myśli autora Personal knowledge. Sytuacja ta wydaje się swoista filozoficzno-historyczna zagadka, która zachęca do zgłębiania tego tematu.

Koncepcja Polanyiego jest próbą holistycznego ukazania procesów, które prowadzą do powstawania i konstytuowania się wiedzy naukowej. Filozof uwzględnia bardzo wiele czynników, mających udział w poznaniu naukowym, chcąc uniknać wszelkiego redukcjonizmu, którego jest zdecydowanym przeciwnikiem. Koncepcja wiedzy Polanyiego uwzględnia takie czynniki, jak: osobista, milcząca wiedza obecna w poznaniu, zaangażowanie poznającego i żywione przez niego intelektualne pasje, a także przynależność do konkretnej grupy społecznej, w której współdzielona jest wiedza, tradycja, obraz świata, język i cała szeroko pojęta kultura. Za cała koncepcją Polanyiego stoi podstawowe pytanie o genezę i warunki powstawania problemów naukowych, co czyni ja przede wszystkim teoria dla kontekstu odkrycia naukowego. Koncepcję tę węgierski filozof stworzył w opozycji do filozofii krytycznej i pozytywistycznej, postulując nową koncepcję genezy i rozwoju nauki. Tym poglądem, który Polanyi chciał zwalczyć na arenie filozofii nauki, jest stanowisko, zgodnie z którym wiedza jest o tyle obiektywna, o ile jest zupełnie pozbawiona wszelkich czynników osobistych, przekonań i procedur, które nie dają się sformalizować i sprawdzić empirycz-

nr 262, s. 106-134 oraz tenże, Zagadnienie wiedzy niejawnej, „Przegląd Filozoficzny", 2008, nr 3 (67), s. 147-163.

3 Por. W. Sady, Fleck o społecznej naturze poznania, Warszawa 2000.

4 Por. J. Życiński, Elementy filozofii nauki, Tarnów 1996.

5 Por. E. Pietruska-Madej, Odkrycie naukowe. Kontrowersje filozoficzne, Warszawa 1990, s. 207-224. 
nie lub dedukcyjnie. Według węgierskiego myśliciela, to filozofia krytyczna doprowadziła do sformułowania złudnego, nieosiagalnego ideału wiedzy obiektywnej, która nie tylko nie oddaje rzeczywistego procesu poznania naukowego, ale fałszujacc go, może szkodzić nauce, wytyczając jej nierealne cele. Według Polanyiego bowiem nie da się opisać nauki bez uwzględnienia koniecznie występujących w nauce czynników osobistych - bez ujęcia osobowego udziału poznającego we wszystkich aktach poznania i rozumienia. Tym samym węgierski badacz rezygnuje z pojęcia obiektywizmu na rzecz bliższego realiom opisu genezy nauki, uwzględniającego elementy wykluczające empiryczne pomiary.

Jednym z ważniejszych tego typu czynników w opisie fenomenu nauki, do których odwołuje się Polanyi w swoim bodaj najważniejszym dziele, Personal knowledge ${ }^{6}$, sa pasje intelektualne. Są nierozerwanie związane $\mathrm{z}$ wiedzą osobistą - elementem centralnym filozofii nauki i poznania węgierskiego badacza, gdyż są ukoronowaniem tego, co osobiste w procesie naukowotwórczym, którego właściwym podmiotem są osoby konkretnych badaczy. Co więcej, pasje intelektualne stoja, według wspomnianego filozofa, u początku nauki. To z nich właśnie wypływa ruch, który prowadzi do powstawania teorii naukowych, mają więc kluczowe znaczenie dla rozwoju wiedzy.

\section{Pasje naukowe w koncepcji Personal knowledge}

Jest coś paradoksalnego w stwierdzeniu, że tak dużo w nauce zależy od pasji. Pasje bowiem kojarzą się z popędami, emocjami, sfera irracjonalną w człowieku. Jak połączyć naukę, tak często uznawaną za szczyt możliwości ludzkiego rozumu, z niezrozumiała siłą rządzącą człowiekiem? Odpowiedź na to pytanie nie jest prosta. Polanyi, wprowadzając pojęcie pasji intelektualnej, odcina się od obiektywizmu wprost, przenoszac akcent na czynniki niezobiek-

6 M. Polanyi, Personal knowledge: Towards a post-critical philosophy, London 1962, preprint: Taylor \& Francis e-Library, 2005. 
tywizowane, czyli w tym przypadku takie, które nie dają się zmierzyć empirycznie. Sama definicja intelektualnych pasji nie pojawia się w tekście Personal knowledge. Samo to pojęcie, chociaż intuicyjnie zrozumiałe, z punktu widzenia semantyki jest rozmyte. Polanyi starał się przybliżyć tę ideę poprzez dość szczegółowy opis fenomenu występowania owych pasji w procesie powstawania nauki, czyli de facto procesie tworzenia teorii naukowych. Przy tym jednak cała koncepcja węgierskiego badacza będzie musiała bronić się przed zarzutem psychologizacji.

Mówiąc o źródłach nauki, Polanyi bierze pod uwagę ich najbardziej pierwotne podłoże, sugerując, że procesy poznawcze i naukotwórcze są inicjowane emocjonalnymi reakcjami. Emocjonalne reakcje zaś mają miejsce dzięki złożonym procesom chemicznym w ludzkim organizmie. Perspektywa taka pokazuje charakterystyczną dla węgierskiego myśliciela postawę. Nie da się według niego bowiem oddzielić nauki od tworzącego ją człowieka, a to, co człowiekiem kieruje, jego możliwości poznawcze, w tym także biologiczne uwarunkowania i nastawienie, wyznaczaja, czym jest nauka.

Upatrywanie źródeł nauki w ludzkich reakcjach emocjonalnych może być kontrowersyjne, kiedy traktuje się ją jako ukoronowanie ludzkiej racjonalności. Zazwyczaj bowiem nie jesteśmy skłonni kojarzyć nauki z pierwotnymi instynktami. Dzieje się tak dlatego, że z czasem, wraz z rozwojem języka, stała się ona bardziej wysublimowana i skomplikowana. Jednak system, jakim dzisiaj jest nauka, niezależnie od tego, czy postrzegamy go jako system racjonalny i obiektywny, został ugruntowany dzięki wiodącym ludzi ku poznaniu bodźcom, które Polanyi nazywa intelektualnymi pasjami; a przyjemność, jaką ludzie czerpią z poznania, jest nieodłącznym składnikiem, bez którego nauka nie mogłaby zaistnieć. Polanyi sugeruje, że nauka jest wynikiem złożonych procesów, majacych początek w biologicznych reakcjach i pewnych predyspozycjach, które sprawiaja, że człowiek czerpie radość z intelektualnych osiagnięć - takich jak naukowe poznawanie świata.

Intelektualna przyjemność poznawania związana jest z kolei, według Polanyiego, ze swoistym przeżyciem naukowego pięk- 
na. Teoria naukowa, jak twierdzi Polanyi, „posiada nieartykułowany składnik, darzący uznaniem jej piękno, i jest to podstawa wiary w to, że teoria jest prawdziwa"7. Jak czytamy dalej w Personal knowledge:

Teoria naukowa, która zwraca uwagę na swoje własne piękno i częściowo opiera na tym swoje roszczenie do ukazywania empirycznej rzeczywistości, jest zbliżona do dzieła sztuki, które zwraca uwagę na swoje własne piękno, jako znak artystycznej rzeczywistości. Jest zbliżona także do mistycznej kontemplacji natury [...]. Ogólnie rzecz biorąc, nauka, z racji swojego pełnego pasji rysu, znajduje się wśród wielkich systemów wypowiedzi, które starają się ewokować i narzucać poprawne modusy czucia. W nauczaniu wszelkich swoich rodzajów formalnych osiagnięć, nauka funkcjonuje tak jak sztuka, religia, moralność, prawo i inne składowe kultury ${ }^{8}$.

Dotykamy w tym miejscu kolejnych charakterystycznych dla Polanyiego koncepcji. Nie tylko docenia on piękno w nauce, ale czyni przy tym jeszcze mocne założenie ontologiczne, że piękno to wypływa z kontemplacji i ujęcia ukrytej, choć realnie istniejacej rzeczywistości. Teza ta widoczna jest we wszystkich rozważaniach węgierskiego filozofa. Jest uznana za oczywistość, która jawi się każdemu naukowcowi w jego faktycznej działalności naukowej - z punktu widzenia filozoficznego i metodologicznego jednak ciężko uznać ją za ostatecznie uzasadniona. Przy okazji nasuwa się pytanie, czy zatem jednak niezgoda innych badaczy co do tego założenia nie podważyłaby go znacząco?

Z jednej strony mamy tutaj do czynienia z podejściem, które opiera się na opisie naukowych procedur, do których można zaliczyć indywidualne przeżycie piękna związanego z wiara, że odkrywana jest prawda o rzeczywistości, z drugiej strony obserwacje i przemyślenia Polanyiego są uogólnione i podniesione do rangi twierdzeń natury epistemologicznej i ontologicznej. Nie sposób do tego jednoznacznie stwierdzić, czy ontologiczna teza o związku piękna

\footnotetext{
M. Polanyi, Personal..., dz. cyt., s. 141.

8 Tamże, s. 141.
} 
i prawdy nie była pierwotnym przedzałożeniem filozofa. Według Polanyiego, docieranie do fenomenu piękna jest swoistą wskazówką w tworzeniu teorii naukowych - jest znakiem, że zbliżamy się zarazem do prawdy. Ukazując ukrytą rzeczywistość, wzbudzając poczucie piękna, teoria zapewnia o swojej prawdziwości. Polanyi zatem, zgodnie z tradycją antyczna, wiąże piękno z prawda; powstawanie nauki natomiast w sposób innowacyjny wiąże z innymi przejawami kultury - sztuka, religia, prawem.

Akcentowanie kulturowego podłoża nauki jest charakterystyczne dla koncepcji Polanyiego. Tuchańska szczególnie podkreśla ten wątek myśli Polanyiego, nazywając całą jego koncepcję nauki kulturalistyczną ${ }^{9}$ Faktycznie, łatwo zauważyć w całym tekście Personal knowledge, że perspektywa ta jest konsekwentnie utrzymywana i rozwijana. Nauka, jaka ją widzi Polanyi, funkcjonuje w taki sam sposób, jak inne instytucje kultury, nawet religia czy sztuka. Stanowisko to może budzić pewne wątpliwości. Można się zgodzić, że zarówno sztuka, jak i nauka należą do wytworów kultury, czyli szeroko pojętej działalności człowieka, chociaż w przypadku religii czy moralności stanowisko takie znalazłoby zapewne wielu oponentów. Czym innym jest jednak stwierdzenie, że wszystkie te dziedziny funkcjonuja w taki sposób. Obie te, nieoczywiste z początku tezy, węgierski filozof będzie się starał udowodnić w całej swojej rozprawie, odwołując się do czynników związanych z ludzkimi procesami poznawczymi. Przede wszystkim, jak łatwo da się zauważyć, dla Polanyiego ważna jest ludzka perspektywa w procesie tworzenia dóbr kultury, ta zaś jest nam wszystkim wspólna i przejawia się wszędzie tak samo, jak można przypuszczać, że założył autor. Ta ludzka perspektywa związana jest z naszymi możliwościami i funkcjami poznawczymi, które ukształtowały się z czasem w naszym rozwoju. Wspólne wszystkim zdobyczom kulturowym jest to, że człowiek tworzy je kierowany swoimi pasjami poznawczymi, swoimi intelektualnymi preferencjami.

9 Por. B. Tuchańska, Koncepcja poznania..., dz. cyt., s. 105 oraz Personal knowledge. Towards a post-critical philosophy, [w:] Przewodnik po literaturze filozoficznej..., dz. cyt., s. 105. 
W całej swojej koncepcji, opisanej w Personal knowledge, Polanyi wskazuje, że w nauce dużą rolę odgrywa struktura porządku i prawdopodobieństwo, a także naukowe umiejętności i swoiste naukowe znawstwo, jednak wszystkie te składowe bledną przy tym, jak ważne są dla nauki naukowe pasje, dzięki którym nauka docenia swoje własne piękno ${ }^{10}$. Perspektywa taka uniemożliwia ujęcie nauki jako zbioru czy opisu faktów w rozumieniu pozytywistycznym, gdyż takie podejście próbuje zamknać istotę nauki w zupełnym oderwaniu od faktycznego procesu poznawczego właściwego człowiekowi. A proces ten inicjowany jest i kierowany poprzez czynniki przepełnione pasja. Polanyi przytaczał wiele przykładów na poparcie tego stanowiska, przywołując m.in. postać Johannesa Keplera w kontekście XVII-wiecznej rewolucji naukowej.

Pierwsze skojarzenie odnośnie do kategorii pasji, ma ewidentne konotacje emocjonalne. Kojarzy się ona bowiem z pewną siła niekoniecznie ugruntowaną racjonalnie, która domaga się realizacji pożądanego celu. Ten psychologiczny rys pasji jest jak najbardziej obecny w koncepcji Polanyiego, jednak, według węgierskiego filozofa, owe intelektualne pasje mają także swoją logiczną funkcję, która wnosi niezbywalny dla nauki element. Pasje, w ujęciu Polanyiego, odpowiadaja podstawowym właściwościom naukowych twierdzeń i moga zatem być uznane za słuszne lub błędne, w zależności od tego, czy uzna się lub zaprzeczy danej własności ${ }^{11}$. Wydaje się to być zabiegiem, który ma ugruntować logicznie pasje, aby były czymś więcej niż tylko nie do końca uzasadnionym porywem emocji. Jest to próba racjonalizacji procesu powstawania nauki, który ujmuje element pozaracjonalny, jakim są intelektualne pasje. Niestety, owego watku Polanyi nie rozwija znaczaco i wystarczająco. Stwierdzenie, że pasje odpowiadają podstawowym własnościom naukowych twierdzeń sprowadza się właściwie do tego, że mogą wieść w słusznym lub niesłusznym kierunku, w zależności od punktu widzenia późniejszej akceptacji, pociagającej badacza idei. Innymi słowy, naukowiec zainteresowany danym problemem ba-

\footnotetext{
10 Por. M. Polanyi, Personal..., dz. cyt., s. 141.

${ }^{11}$ Por. tamże, s. 142.
} 
dawczym podąża za pasją intelektualna, która - jak twierdzi Polanyi - niezależnie od świadomości badacza prowadzi go w stronę realizacji naukowych idei, odkrywania pociagającego piękna ukrytego w badanej rzeczywistości, tym samym gruntując naukę. Dotykamy tutaj platonicznego rysu koncepcji Polanyiego i próby racjonalizacji koncepcji - pasje intelektualne naukowców wyznaczaja tor rozwoju nauki, a te z kolei warunkowane sa przez doświadczenie prawdy lub piękna, które są niezależne od nich samych.

W wielu przypadkach badacz może jednak pomylić się co do tego, czy droga, która wybrał, nie jest ślepą uliczka. W pewnym sensie nie ma żadnej gwarancji sukcesu tych poszukiwań; jednak naukowe idee zostają poddane pewnej weryfikacji - albo zostają wpisane w kanon powszechnej wiedzy, albo zostaja zmarginalizowane i odchodzą w zapomnienie. W tym sensie, jak się wydaje, można mówić o weryfikacji pasji naukowych. Czy jest to jednak wystarczajace wyjaśnienie wszystkiego - na przykład tego, w jaki sposób naukowcy osiagają upragniony kontakt z badaną rzeczywistością i czy faktycznie kontakt ten jest niezafałszowany i prowadzi do rzetelnej wiedzy? Z punktu widzenia filozofii nauki węgierskiego uczonego, sam fakt, że nauka jest tworzona i istnieje popychająca ludzi do tego pasja, jest argumentem za możliwością adekwatnego kontaktu z rzeczywistościa; biorac pod uwagę osobisty charakter wiedzy, naukowcy wierza, że osiagają wiedzę o ukrytych, ale realnie istniejących aspektach naszego świata. Tłumaczenie to być może nie zadowoli wszystkich, ale trzeba zaznaczyć, że nie jest to jednak jedynie problem koncepcji Polanyiego - sa to pytania, na które do tej pory nie znaleziono satysfakcjonującej wszystkich odpowiedzi. Koncepcja naukowych pasji natomiast wiele mówi o procesie powstawania nauki z punktu widzenia naukowca, dlatego Polanyi podkreślał ich znaczenie i funkcjonowanie w procesie zdobywania wiedzy.

W koncepcji węgierskiego uczonego pasje intelektualne spełniają trzy bardzo istotne dla nauki funkcje: selektywne, perswazyjne i heurystyczne. Pasje o charakterze selektywnym pełnią rolę swoistego kryterium, decydującego o tym, co jest naukowe, a co do nauki w ogóle nie należy. Funkcja heurystyczna wyraża się w wyznaczaniu kierunku badań i generowaniu odkryć naukowych; 
perswazyjna funkcja pasji żywionych przez naukowców wyraża się natomiast w tym, że dążą oni do osiagnięcia konsensusu w sytuacji konfliktów i kontrowersji naukowych. Opis tych funkcji jest w istocie opisem bardzo ważnych mechanizmów funkcjonujacych w nauce, którym warto przyjrzeć się z uwagą. W tym miejscu kilka słów warto poświęcić kwestii funkcji selektywnej pasji intelektualnych.

\section{Selektywna funkcja pasji intelektualnych}

Bardzo interesujące jest, że tylko niewielka liczba faktów leży tak naprawdę w zainteresowaniu nauki. Nauka nie zajmuje się badaniem wszystkich faktów. Skąd jednak wiemy, czym nauka powinna się zajmować, a co jest dla niej zupełnie nieistotne? Pytanie to jest właściwie pytaniem o istotę nauki, o jej kompetencje i zakres. Znajduje się ono u podstaw zainteresowań filozoficznych Polanyiego, a odpowiedź na nie budowana jest stopniowo wraz z rozwojem jego koncepcji. Warto przy tym zaznaczyć, że węgierski filozof, by odpowiedzieć na to pytanie, ewidentnie odwoływał się do praktycznego aspektu zagadnienia, koncentrując się na tym, jak przebiega faktyczny proces budowania teorii naukowych (stanowiacych rdzeń i kwintesencję nauki). Niebagatelny wpływ na owe podejście ma z pewnościa fakt, że autor przez całe swoje życie sam parał się działalnością naukową w zakresie chemii, fizyki i ekonomii.

Do wyjaśnienia tego zagadnienia Polanyi wykorzystał kategorię pasji selektywnych. Według węgierskiego badacza, jeśli chcemy adekwatnie mówić o nauce, musimy wprowadzić opis, a zatem także i język, który umożliwiałby ujęcie swoistej ludzkiej pasji (notabene, język taki jest odpowiednim językiem do opisu nie tylko nauki, ale w takiej samej mierze dzieła sztuki i godnych uczynków ${ }^{12}$ ). To właśnie intelektualne pasje napełniają obiekty emocjami, które kieruja na dalszy tor naukowe postępowanie. One czynią obiekty i zagadnienia zachęcającymi lub odpychajaccymi, cennymi lub bez-

${ }^{12}$ Por. tamże, s. 143. 
wartościowymi dla nauki ${ }^{13}$. W tym sensie, chociaż może to wydawać się paradoksalne (a już na pewno mogło wydawać się takim w czasie wydania Personal knowledge), pasje odgrywaja niebagatelną rolę dla wyznaczania zainteresowań nauki, a zatem jej zakresu. Funkcja naukowych pasji, na którą zwracał uwagę Polanyi, polegała więc na tym, że pomagały one rozdzielać dające się udowodnić fakty, które leżą w zainteresowaniu nauki, od tych, które wykraczaja poza to zainteresowanie. Pasje naukowe służą za przewodnika w szacowaniu, co jest dla nauki doniosłe i ważne, a co ma mniejszą lub znikomą ważność.

Według Polanyiego, istnieją trzy czynniki, które czynią dane zagadnienie cennym dla nauki:

(1) pewność twierdzenia

(2) zgodność z całością systemu

(3) rzeczywiste zainteresowanie ${ }^{14}$.

Jak twierdzi Polanyi, dwa pierwsze z tych kryteriów są ściśle naukowe; ostatnie jednak wykracza daleko poza. Co więcej, sa one w praktyce stosowane łącznie, a niedostatki jednego mogą być rekompensowane poprzez doniosłość i doskonałość innego. Istotnym elementem także jest fakt, że są one stopniowalne - w im większym stopniu dane naukowe twierdzenie, czy też cała teoria, je posiada, tym bardziej staje się cenna dla nauki ${ }^{15}$. Jako przykład funkcjonowania tego kryterium węgierski filozof podaje teorię ewolucji gatunków (neodarwinizm). W czasach działalności Polanyiego była już powszechnie uznana, jednak, jak stwierdza autor Personal knowledge, jest niewiele bezpośrednich dowodów na jej prawdziwość. Cieszy się jednak ogromnym szacunkiem i uznaniem naukowców, ponieważ pasuje do mechanistycznego systemu wszechświata i dotyczy powstania człowieka - jednej z najbardziej interesujaccych dla nas kwestii ${ }^{16}$. Rzeczywiste zainteresowanie naukowców danymi zagadnieniami jest ważnym czynnikiem, który

\footnotetext{
${ }^{13}$ Por. tamże, s. 143.

${ }^{14}$ Por. tamże, s. 143.

15 Por. tamże, s. 143.

${ }^{16}$ Por. tamże, s. 144.
} 
wpływa na rozwój nauki, pomijanym często przy opisie naukowych zmagań poszczególnych ludzi tworzacych naukę. Choć Polanyi przykłada największą wagę do aspektu rzeczywistego zainteresowania naukowców jako elementu decydujacego w procesie powstawania nauki, to warto też zwrócić uwagę na samo pojęcie pewności twierdzenia, które z punktu widzenia koncepcji węgierskiego badacza również wydaje się być dość rozmyte i podlegające indywidualnej ocenie, co może sugerować zarzut psychologizacji.

Naukowcy, w swojej praktyce badawczej, dokonują wyborów, szacunków, a często także zgadują. Muszą rozpoznać, co jest w nauce trywialne, a co błędne. Podejmowane zagadnienia moga okazać się niezgodne z naszymi oczekiwaniami i podejrzeniami, ale to upodobanie, które leży u podłoża samego wyboru pomiędzy podejmowanymi zagadnieniami, ostatecznie jest - według Polanyiego - podyktowane pragnieniem realizacji ideału naukowego piękna, wypływającego z możliwości naukowego ujęcia rzeczywistości ${ }^{17}$. Polanyi znów wyraźnie zaznacza tutaj swoje stanowisko, opisujące, procesy naukowe w kategoriach pozaracjonalnych, tęskniąc jednak i próbujac uratować nadrzędne, obiektywne wartości, które w tych procesach ostatecznie mają być odkrywane, fundując ontologiczne podstawy nauki.

Pasje selektywne stanowią ostatecznie przyjmowane praktycznie kryterium demarkacyjne. Zgoła różni się ono jednak od Popperowskiego kryterium demarkacji, które w sposób obiektywny, logiczny, ma oddzielić naukę od metafizyki. U Polanyiego naukowcy, dzięki swoim pasjom, wyznaczają pole aktualnych badań w swoich dziedzinach, szacując także, które zagadnienia są istotne dla rozwiązania danego naukowego problemu. Interesujace dla naukowców problemy w obrębie danej dziedziny naukowej, stają się aktualnymi problemami nauki. Co więcej, selektywne pasje wyznaczaja $\mathrm{u}$ podstaw to, co w szerokim sensie jest naukowe, a co nie jest. Polanyi wydaje się sugerować, że jest w człowieku coś, co można nazwać pewnym naukowym zmysłem. Zmysł ten nakierowany jest

${ }^{17}$ Por. tamże, s. 143. 
na realizację naukowego piękna. Jest to upodobanie uprawiania nauki w dokładnie określony sposób. Można powiedzieć w duchu Ludwiga Wittgensteina, że naukowcy żywią chęć do uprawiania gry, której obowiązujące zasady sami wymyślają. Jak twierdzi Polanyi, upodobanie to nie jest jednak całkiem subiektywne ani zupełnie dowolne. Naukowe piękno, aby mogło zostać w pełni zrealizowane, musi być związane z prawdac. Teoria naukowa, aby mogła być piękna, musi być również prawdziwa ${ }^{18}$. Jest to bardzo interesująca myśl. Po pierwsze, jak już wspomniano, węgierski filozof wiązał ściśle piękno z prawda, hołdując klasycznym koncepcjom. Po drugie, to powiązanie staje się tutaj interesującym argumentem za obiektywizmem nauki, który Polanyi usiłuje ocalić pomimo wprowadzania wielu wątków związanych z subiektywizmem. Można go sparafrazować w następujaccy sposób: naukowcy, wiedzeni przez swoje pasje, tworzą naukę i zasady uprawiania nauki. Moga je rozwijać twórczo, o ile spełniane sa podstawowe cele - doświadczenie piękna poprzez osiaganie kontaktu z ukrytą rzeczywistością. Teoria naukowa zatem nie może być dowolna. Nie może być jedynie konstruktem myślowym, zaistniałym przypadkowo i niespójnie. Jeżeli nie będzie uznana za prawdziwą i jeśli nie będzie za nią szła wiara i przekonanie, że jest prawdziwa, to nie spełni podstawowych kryteriów, które naukowcy sami dla siebie wytyczyli. Czy ta wiara i przekonanie o prawdziwości teorii są wystarczającymi argumentami - nadal pozostaje kwestią otwarta. Jednak, wobec problemów ze stwierdzeniem prawdziwości teorii naukowych, jest ciekawym pomysłem. Polanyi nie tyle starał się rozwiązać problem owej prawdziwości na płaszczyźnie klasycznego kryterium prawdy (pomijając problem możliwości takiego rozwiązania w ogóle, który wydawał się dla niego poważny), co być może raczej zbliżał się takim rozumowaniem do pojmowania prawdziwości w pewnym sensie na sposób pragmatyczny. Nie chodzi tutaj jednak stricte o użyteczność, lecz o możliwość zrealizowania założonego przez siebie celu, o uzyskanie intelektualnej przyjemności z teorii.

${ }^{18}$ Por. tamże, s. 141. 
W praktyce jednak, co trzeba podkreślić, często zdarza się, że tym, co w nauce uznane jest za prawdziwe, jest to, co naukowcy uznają za prawdziwe, co czyni kryterium zawężonym kryterium społeczne. To naukowcy mają decydujący głos w akredytacji teorii naukowych. Laikom niezwykle ciężko ocenić, która z konkurencyjnych teorii jest prawdziwa. Co ciekawe, spory pomiędzy naukowcami dalekie są od chłodnego ważenia argumentów (o czym Polanyi pisze przy zagadnieniu pasji perswazyjnych). Wynikałoby z tego, że naukowym jest to, co naukowcy uznają za naukowe. Co za tym idzie, słynna idea kryterium demarkacji Karla Poppera byłaby wartościowa, w ujęciu Polanyiego, tylko wówczas, jeśli sami naukowcy uznaliby ją za wartościową i praktycznie przydatną. Oczywiście wybór ten powinien być w tym kontekście usprawiedliwiony nadrzędnym ukierunkowaniem na prawdę i piękno teorii, ale powstaje wtedy pewna kolistość odniesień. Pojawia się zatem problem natury logicznej. Koncepcja Polanyiego w tym miejscu nosi znamiona błędnego koła i jest logicznie niesatysfakcjonująca. Mówi jednak wiele o tym, jaki jest faktyczny przebieg uznawania danych tez za prawdziwe. Odbiorca znajduje się zatem w trudnym położeniu $-\mathrm{z}$ jednej strony docenia doniosłość opisu powstawania nauki, z drugiej - operuje intuicyjnie tylko oczywistymi pojęciami i mechanizmami, szukając spójnego połączenia dla czynników pozaracjonalnych i obiektywistycznych.

Jednakże koncepcja pasji intelektualnych Polanyiego, pomimo wszelkich zarzutów, stanowi ciekawe zagadnienie nie tylko na tle koncepcji wiedzy osobistej, ale także w kontekście całej filozofii nauki. Z punktu widzenia tej pierwszej, jest jednym z kluczowych elementów myśli węgierskiego filozofa, gdyż odpowiada na najbardziej interesujące pytania dotyczace nauki, będac przy tym wyrazem tego, co najbardziej osobiste w poznaniu naukowym. Z punktu widzenia filozofii nauki natomiast jest oryginalna propozycja która łączy analize procesu powstawania nauki z uwzględnieniem jej historii i elementów, jakie do poznania wnoszą zarówno perspektywa twórczej jednostki, jak i całego, wpływającego na nią społeczeństwa. Cała myśl Polanyiego cechuje - bardzo oryginalne na owe czasy i pretendujace do holistycznego ukazania nauki - przekona- 
nie, że nauka jest wytworem kultury człowieka i funkcjonuje w pewien sposób analogicznie do sztuki i religii. Nauka w tym ujęciu powstaje w wyniku złożonego procesu, angażującego poznającego człowieka, i wiążą się z nią takie elementy, jak: milcząca wiedza, intelektualne pasje, a także uczestnictwo we wspólnocie językowej i badawczej.

Intelektualne pasje, jako czynnik wiedzy osobistej, wpisuja się w koncepcję nauki, która zrywa z tradycja filozofii krytycznej i pozytywistycznej. Sprzeciwiają się poglądowi, że nauka jest, lub powinna być, zbiorem niezależnych od poznającego podmiotu faktów, a wszelkie przejawy indywidualności człowieka (takie jak jego pasje i związane z nimi przekonania, zaangażowanie i oryginalne stosowanie zastanych metod naukowych) powinny być z niej usunięte. Wedle tego poglądu, tylko w ten sposób zrealizowany może zostać ideał wiedzy obiektywnej. Ideał taki jest jednak, według Polanyiego, niemożliwy do osiagnięcia, a przekonanie, że jest inaczej, jest nie tylko złudne, ale szkodliwe dla nauki i jej rozwoju. Jak bowiem sądził węgierski filozof, analizując historię i metodologię nauki, u jej podstaw i w całym procesie jej powstawania, to właśnie czynnikom należącym do wiedzy osobistej, nie zaś sformalizowanym procedurom, mającym zapewnić obiektywność, zawdzięczamy naukowa wiedzę. Proces powstawania i funkcjonowania nauki w bardzo interesujaccy i oryginalny sposób udało się Polanyiemu pokazać najbardziej obrazowo właśnie przy użyciu kategorii pasji intelektualnych, co dodatkowo czyni ją znacząca nie tylko dla całej koncepcji wiedzy osobistej, ale także dla filozofii nauki.

Jak usiłował wykazać Polanyi, kształtując swoją koncepcję genezy i kontekstu powstawania nauki, to intelektualna pasja i przyjemność, czerpana z poznania, stoją u rzeczywistych podstaw odkryć naukowych. Ich fundamentami sa pewnego rodzaju instynkty i bodźce emocjonalne, a zatem podstawy nauki sa biologiczne, przy czym jej dzisiejszy kształt wynika z rozwoju człowieka i jego języka. Myśl ta stanowi oryginalne podejście węgierskiego badacza, które w dzisiejszych czasach znajduje swoiste odbicie w kognitywistyce. Polanyi jednak, oprócz tych nowoczesnych poglądów, wprowadza także do koncepcji pasji elementy klasycznego myślenia, 
łącząc dążenie do prawdy $\mathrm{w}$ nauce $\mathrm{z}$ przeżyciem intelektualnego piękna, które wynika z uchwycenia realnie istniejącej rzeczywistości. Działalność naukowa człowieka, kierowana pasjami, jest zatem czymś więcej, niż tylko biologicznym odruchem, jest wyrazem poszukiwania harmonii i piękna, które odzwierciedlaja się w prawdzie na temat rzeczywistości. Sam fakt, jak dochodzi do uzyskania tego kontaktu, czyli de facto osiagnięcia rzetelnej wiedzy, nie jest dobrze wyjaśniony w koncepcji, jednak pozostałe mechanizmy naukowe zostały ujęte, przy pomocy pasji, bardzo dobrze.

Wskazane mechanizmy w Personal knowledge zostały ukazane za pomocą wyszczególnienia funkcji, jakie pasje intelektualne spełniaja w nauce - sa to funkcje selektywne, heurystyczne i perswazyjne. Analiza pasji o charakterze selektywnym pokazuje, jak w praktyce naukowcy decydują o tym, co należy do nauki i jej zainteresowań. Bowiem pod wszystkimi zagadnieniami, które bada nauka, kryją się osobiste pasje naukowców i ich zainteresowania - ostatecznie to one decydują o tym, co wchodzi w skład badanych zagadnień.

Wiarygodny opis powstawania nauki, dobrze tłumaczacy jej mechanizmy i prawa rozwoju, jest najmocniejszą stroną koncepcji Polanyiego. Pojęcia, którymi operuje, pozostawiają jednak, mówiąc przenośnie, semantyczny niedosyt. Odsyłaja one co prawda do intuicyjnie zrozumiałych idei, wprowadzaja jednak pewien zamęt logiczny. Polanyi, nie zgadzając się z ideą nauki jako zobiektywizowanego tworu, szukał rozwiązania i ujęcia, z jednej strony, wszystkich znanych mu z praktyki badawczej aspektów nauki, z drugiej - ratując obiektywne i racjonalne oblicze nauki poprzez wprowadzenie niezależnych i obiektywnych wartości prawdy i piękna jako celu teorii naukowej. Taka fuzja czynników pozaracjonalnych, jakimi sa choćby intelektualne pasje, oraz obiektywnych wartości, jak prawda i piękno, stanowią mieszankę, która nie w pełni satysfakcjonuje, gdyż jest podatna na mocną krytykę i zarzuty psychologizacji i subiektywizmu. Z pewnością jest to jeden z powodów, dla którego myśl Polanyiego bywa marginalizowana. Z drugiej strony jednak nie można jej odmówić, i nie można nie docenić, ważnych aspektów i ukazania interesujących motywów w nauce. Stąd też 
zapewne niektóre jej idee zakiełkowały w pracach innych myślicieli i prawie niepostrzeżenie zadomowiły się w nowoczesnej wizji nauki. Problem rozważań Polanyiego, usiłujący uwzględnić czynniki pozaracjonalne $\mathrm{w}$ nauce, utrzymujac jednak solidne ontologiczne podstawy nauki jako kontaktu z realnie istniejąca rzeczywistościa, wyznaczają wciąż żywy problem filozofii nauki.

\section{Bibliografia}

1. E. Pietruska-Madej, Odkrycie naukowe. Kontrowersje filozoficzne, Warszawa 1990 , s. 207-224.

2. M. Polanyi, Personal knowledge: Towards a post-critical philosophy, London 1962, preprint: Taylor \& Francis e-Library, 2005.

3. W. Sady, Fleck o społecznej naturze poznania, Warszawa 2000.

4. B. Tuchańska, Koncepcja poznania i nauki Michaela Polanyi'ego, „Acta Universitatis Wratislaviensis", Socjologia XV: Nauka, demokracja, autorytaryzm. Społeczne i kulturowe wymiary nauki, red. W. Sitek, Wrocław 1994, s. 105-127 oraz Personal knowledge. Towards a post-critical philosophy, [w:] Przewodnik po literaturze filozoficznej XX wieku, red. B. Skarga, Warszawa 1994, s. 400-405.

5. I. Zmyślony, Filozof nauki czy teoretyk poznania? Przyczynek do badań nad pogladami filozoficznymi Michaela Polanyiego, „Filozofia Nauki”, R. XVI, 2008.

6. J. Życiński, Elementy filozofii nauki, Tarnów 1996.

\section{Intellectual passions and their selective function in Michael Polanyi's Personal knowledge concept of scientific knowledge}

This paper shows philosophical views of Michael Polanyi, in the context of his greatest work Personal knowledge: Towards a post-critical philosophy. In his study, Polanyi presents the original concept of science and knowledge, which include tacit components, such as: the personal, tacit knowledge, personal engagement, intellectual passions and participation in the scientists community, which shares the same tradition, language, frameworks and culture. All that makes the philosophy of Polanyi situated against the concept of objectivity in 
science which excludes personal participation in act of knowing and creating knowledge. As one of the most important factors in science formation Polanyi considers intellectual passions, which have heuristic, selective, persuasive functions. The present article is a summary of the main idea of the intellectual passions, in respect of their selective function in science. As Polanyi maintains, scientific passions have a logical function which contributes an indispensable element to science. They charge objects with emotions, making them repulsive or attractive and help distinguish between demonstratable facts which are of scientific interest, and those which are not. Furthermore, scientific passions depend ultimately on a sense of intellectual beauty, which can never be dispassionately defined, as well as the beauty of a work of art or the excellence of a noble action.

\section{Keywords}

Michael Polanyi, Personal knowledge: Towards a post-critical philosophy, personal knowledge, tacit knowledge, tacit knowing, intellectual passions, objectivity, selective intellectual passions 